\title{
MENUMBUHKAN MINAT BACA ANAK USIA SEKOLAH DI PERUMAHAN BUMI MANDALA 2
}

\author{
Febri Giantara ${ }^{1}$, Novi Yanti ${ }^{2}$, Kusdani $^{3}$, Bainar $^{4}$, Mursal $^{5}$ \\ ${ }_{1,2,3,4,5)}$ Program Studi Pendidikan Agama Islam, STAI Diniyah Pekanbaru \\ e-mail: febri@diniyah.ac.id
}

\begin{abstract}
Abstrak
Rendahnya minat baca masyarakat Indonesia pada tahun 2019 berdasarkan data UNESCO merupakan sebuah permasalahan yang harus dipecahkan secara bersama-sama. Salah satu cara yang dapat dilakukan agar minat baca masyarakat Indonesia meningkat adalah dengan menumbuhkan minat baca anak usia sekolah. Sejalan dengan data pernyataan UNESCO permasalahan yang ditemukan di lapangan, pertama tidak terdapatnya perpustakaan masyarakat di perumahan Bumi Mandala 2 Desa Kualu Kabupaten Kampar, kedua anak-anak usia sekolah lebih memilih untuk berkumpul-kumpul dengan teman sebaya untuk bercerita dan ketiga anak-anak usia sekolah lebih banyak bermain untuk mengisi waktu luang. Oleh sebab itu perlu adanya usaha untuk meningkatkan minat baca anak usia sekolah di Perumahan Bumi Mandala 2 Desa Kualu Kabupaten Kampar melalui kegiatan Pengabdian kepada Masyarakat. Metode Pengabdian kepada Masyarakat yang digunakan adalah Participatory Action Research (PAR). Hasil yang diperoleh terjadi peningkatan minat baca anak usia sekolah dikarenakan faktor proses pembelajaran dilakukan di rumah selama pandemi virus corona.
\end{abstract}

Kata Kunci: Minat Baca, Anak Usia Sekolah, PAR

\begin{abstract}
The low reading interest of the Indonesian people in 2019 based on UNESCO data is a problem that must be resolved collectively. One way that can be done to increase the reading interest of the Indonesian people is to foster interest in reading for school-age children. In line with the UNESCO statement data on problems found in the field, firstly there is no community library in Bumi Mandala 2 housing in Kualu Village, Kampar Regency, secondly, school-age children prefer to gather with peers to tell stories and the third school-age children play more for free time. Therefore, it is necessary to have an effort to increase the reading interest of school-aged children in Bumi Mandala 2 Housing, Kualu Village, Kampar Regency through Community Service activities. The Community Service Method used is Participatory Action Research. The results obtained were an increase in reading interest in school-age children due to the learning process being carried out at home during the coronavirus pandemic.
\end{abstract}

Keywords: Reading Interests, School-age children, PAR

\section{PENDAHULUAN}

Membaca merupakan jendela dunia, dengan membaca kita bisa mengetahui dunia dan isinya tanpa harus mengelilinginya. Perkataan ini sering kita dengar atau kita baca, tapi sangat jarang kita amalkan. Salah satu media yang bisa digunakan untuk membaca adalah buku. Buku mempunyai peran yang penting diberbagai bidang, seperti perkembangan sosial, budaya, teknologi, politik dan ekonomi. Ketika buku hanya dijadikan sebuah alat tanpa adanya kegiatan membaca yang bermutu tak ada manfaatnya (Muktiono,2003). Sebuah data UNESCO menunjukkan minat baca masyarakat Indonesia pada tahun 2019 berada di level 60 dari 61 Negara (Cordina,2020). Data tersebut menunjukkan kalau posisi Indonesia berada dinomor dua terbawah. Cukup memperihatinkan bagi dunia pendidikan kita. Pentingnya menanamkan budaya membaca sejak dini merupakan suatu hal yang harus ditanamkan oleh seluruh masyarakat Indonesia pada saat sekarang ini. Hal ini sejalan dengan penelitian (Forsman,2017) yang menemukan bahwa perlu adanya kegiatan membaca dalam kehidupan sehari-hari yang dilakukan oleh pengasuh anak untuk menghasilkan hubungan antar anak dan pengasuh. Penelitian ini mengisyaratkan bahwa salah satu cara menjalin hubungan antara 
anak, pengasuh ataupun orang tua melalui proses membacakan buku kepada anak sejak dini. Untuk melaksanakannya maka orang tua bisa memulai dengan membacakan buku cerita kepada anak.

Selain peran orang tua untuk menumbuhkan minat baca pada anak, guru juga dituntut dapat menumbuhkan minat baca anak di sekolah. Di dalam dunia pendidikan menumbuhkan minat baca pada anak jauh lebih penting daripada anak cepat membaca (Sumitra \& Sumini,2019). Di sekolah untuk menumbuhkan minat baca anak, salah satu cara yang dapat dilakukan oleh guru adalah dengan penggunaan multimedia. Multi media adalah penyajian informasi secara dinamis melalui perantara komputer, dimana multimedia bukan hal baru lagi dalam dunia pendidikan (Umroh,Adi, \& Ulfa, 2019). Mutlimedia ini sangat sesuai dengan kondisi anak sekarang yang merupakan generasi yang sangat dekat dengan dunia teknologi dan gadget.

Di lingkungan masyarakat penanaman nilai-nilai pentingnya membaca pada anak usia sekolah dapat dilakukan dengan cara memotivasi mereka untuk berkunjung keperpustakaan, baik perpustakaan sekolah, perpustakaan daerah, ataupun perpustakaan Lembaga Sosial Masyarakat (LSM) seperti Taman Baca Masyarakat (TBM) (Nafisah, 2016). Perpustakaan yang baik harus memiliki empat kriteria, yaitu pertama pengelola pustaka harus memiliki jaringan luas (network), kedua memiliki akses cepat, tepat, dan mampu memberikan layanan secara maksimal, ketiga memiliki koleksi buku yang lengkap, dan keempat memiliki agenda rutin (mingguan, bulanan, tahunan) untuk mengadakan kegiatan debat, diskusi, seminar atau kegiatan sejenis untuk menambah daya tarik pengunjung.

Motivasi yang bisa dilakukan oleh perpustakaan atau TBM dapat dikelompokkan menjadi dua kelompok, yaitu kelompok program berbasis bacaan dan kelompok program tidak berbasis bacaan (Rahma \& Maulidia,2015). Kelompok program berbasis bacaan menyediakan sebanyak-banyaknya buku bacaan yang dapat menarik minat baca anak pada usia sekolah. Sedangkan kelompok program tidak berbasis bacaan dengan cara membuat kegiatan mendongeng, atau bercerita. Cara lain yang dapat dilakukan untuk menumbuhkan minat baca anak melalui stimulus langsung kepada anak (Kasiyun, 2015). Tidak hanya sekedar meminta anak untuk membaca buku atau membeli buku sebanyak-banyaknya.

Beberapa faktor dapat mempengaruhi anak untuk memiliki minat baca. Faktor yang mempengaruhi anak memiliki minat baca adalah faktor ketersediaan dan jenis buku, faktor situasional, dan faktor orang tua (Maharani,2017). Faktor ini tentunya adalah faktor utama, selain itu juga dibutuhkan faktor pendukukung agar anak memiliki minat baca sejak usia sekolah. Pada artikel Pengabdian kepada Masyarakat yang dilakukan oleh (Khoiruddin, Taulabi, \& Imron, 2016) telihat bahwa TBM yang baik itu seharusnya melakukan kegiatan-kegiatan lomba, bazar buku, menambah koleksi buku bacaan, dan menghias TBM dengan lukisan-lukisan yang memiliki pesan moral terhadap anak-anak.

Pengabdian kepada Masyarakat (PkM) di Perumahan Bumi Mandala 2 Desa Kualu dilakukan oleh dosen-dosen Sekolah Tinggi Agama Islam (STAI) Diniyah Pekanbaru jurusan Pendidikan Agama Islam (PAI). Permasalahan yang ditemukan dilapangan tidak terdapatnya perpustakaan yang dimiliki masyarakat perumahan, jumlah anak usia sekolah sangat banyak dengan data jumlah Kepala Keluarga (KK) 280 orang dan hampir setiap rumah memiliki satu anak usia sekolah. Anakanak perumahan terlihat lebih sering bermain dan berkeliling naik sepeda atau sekedar berkumpul untuk bermain.

Melihat beberapa permasalahan di atas, maka perlu adanya bentuk PkM yang bisa membantu anak-anak usia sekolah untuk mengisi waktu luang atau waktu bermain mereka dengan hal-hal yang lebih bermanfaat. Bentuknya adalah membentuk rumah baca sementara di Perumahan Bumi Mandala 2. Dengan adanya PkM ini nantinya diharapkan adanya peningkatan minat baca anak usia sekolah dan terdapatnya tempat yang nyaman untuk anak mengabiskan waktu luang dengan membaca bersama teman-teman sekitarnya.

\section{METODE}

Metode yang digunakan adalah pendekatan Participatory Action Research (PAR). PAR adalah merupakan salah satu pendekatan yang mengkombinasikan antara penelitian (research) dengan tindakan (action) yang berkelanjutan dan dilakukan secara partisipatif bersama masyarakat (Reason \& Bradbury,2001). Pendekatan ini dipilih karena penelitian yang dilakukan akan 
diharapkan menghasilkan sebuah Taman Baca Masyarakat yang ada di perumahan Bumi Mandala 2 Desa Kualu Kabupaten Kampar. Adapun langkah-langkah penelitian sebagai berikut:

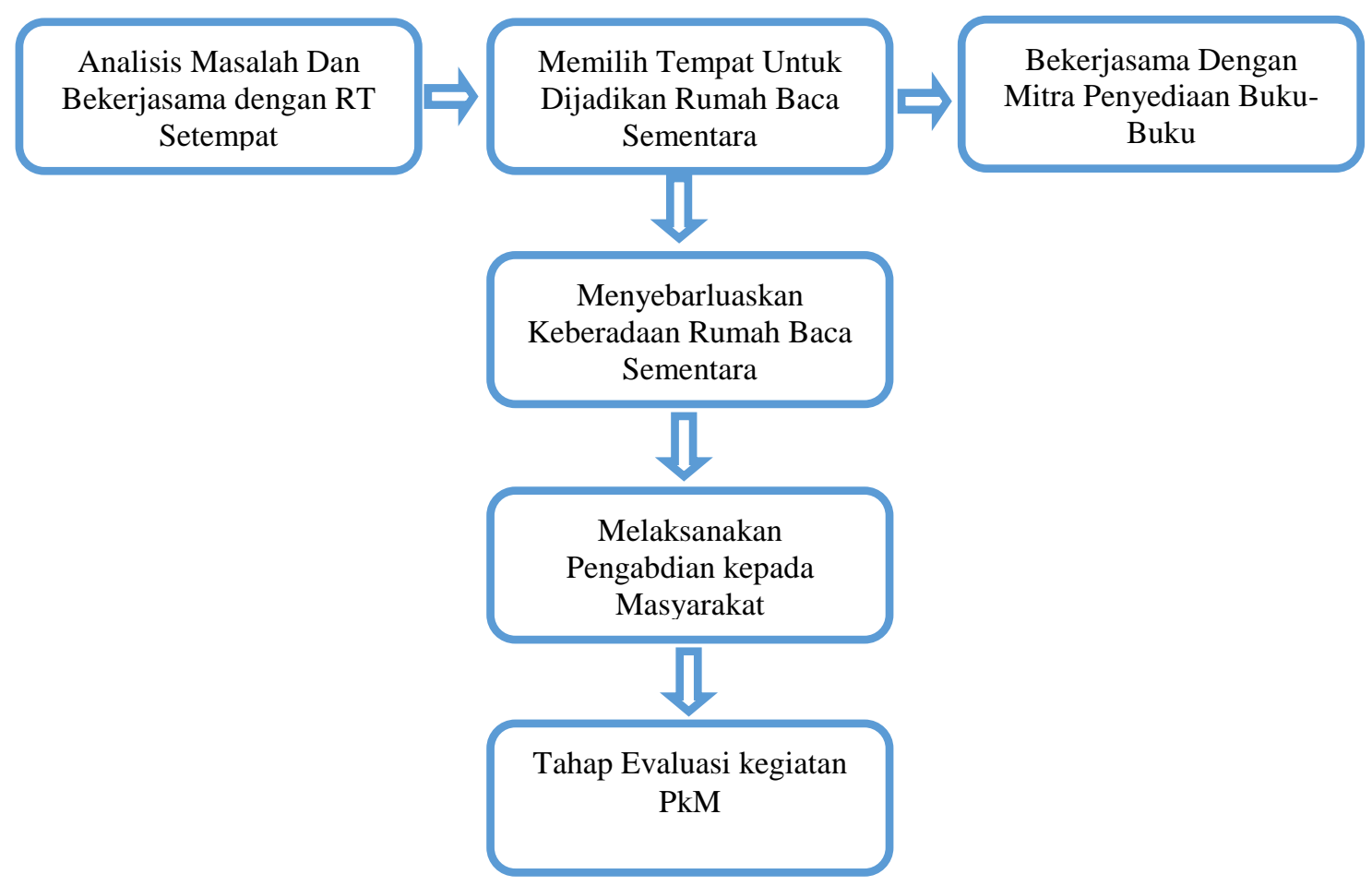

Gambar 1. Siklus PkM

\section{HASIL DAN PEMBAHASAN}

Pengabdian kepada Masyarakat dilakukan selama satu semester pada Tahun Ajaran 2019/2020. Kegiatan ini bersifat mandiri yang seluruh biaya kegiatan ditanggung oleh seluruh anggota kelompok PkM. Pada tahap awal dilakukan pendataan jumlah anak usia sekolah di Perumahan Bumi Mandala 2 Desa Kualu. Setelah proses pendataan dilakukan tahap selanjutnya adalah menentukan salah satu rumah warga yang akan dijadikan rumah baca sementara untuk tempat anak-anak melakukan kegiatan membaca. Rumah warga yang digunakan adalah rumah salah satu anggota PkM yang berdomisili di daerah tersebut. Pemilihan rumah tersebut dikarenakan rumah tersebut sering dikunjungi anak-anak untuk sekedar bermain.

Tahap kedua dilakukan adalah mencari donatur yang bersedia menyerahkan buku-buku bacaan untuk anak ataupun untuk warga sekitar sebagai bahan bacaan. Promosi tersebut dilakukan oleh seluruh anggota PkM melalui media sosial masing-masing. Bentuk sumbangan yang diterima oleh kelompok PkM langsung berupa buku bacaan untuk mempermudah pendistribusian langsung kemasyarakat Perumahan Bumi Mandala 2 Desa Kualu Kabupaten Kampar. Donatur buku yang diterima oleh kelompok PkM dimulai dari teman sejawat pengabdi, masyarakat sekitar, dan seluruh anggota PkM. 


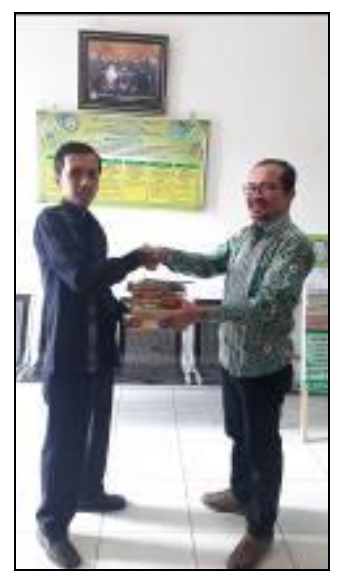

Gambar 1. Penyerahan Donasi Buku Dari Donatur.

Langkah selanjutnya mengaktifkan rumah baca sementara sebagai wadah atau tempat anak usia sekolah untuk menumbuhkan minat baca mereka. Kegiatan menumbuhkan minat baca anak usia sekolah di Perumahan Bumi Mandala 2 Desa Kualu Kabupaten Kampar dilakukan dengan cara memberikan berbagai macam ragam buku bacaan yang bisa dibaca oleh anak dan memberikan buku-buku yang memiliki bentuk permainan di dalamnya.

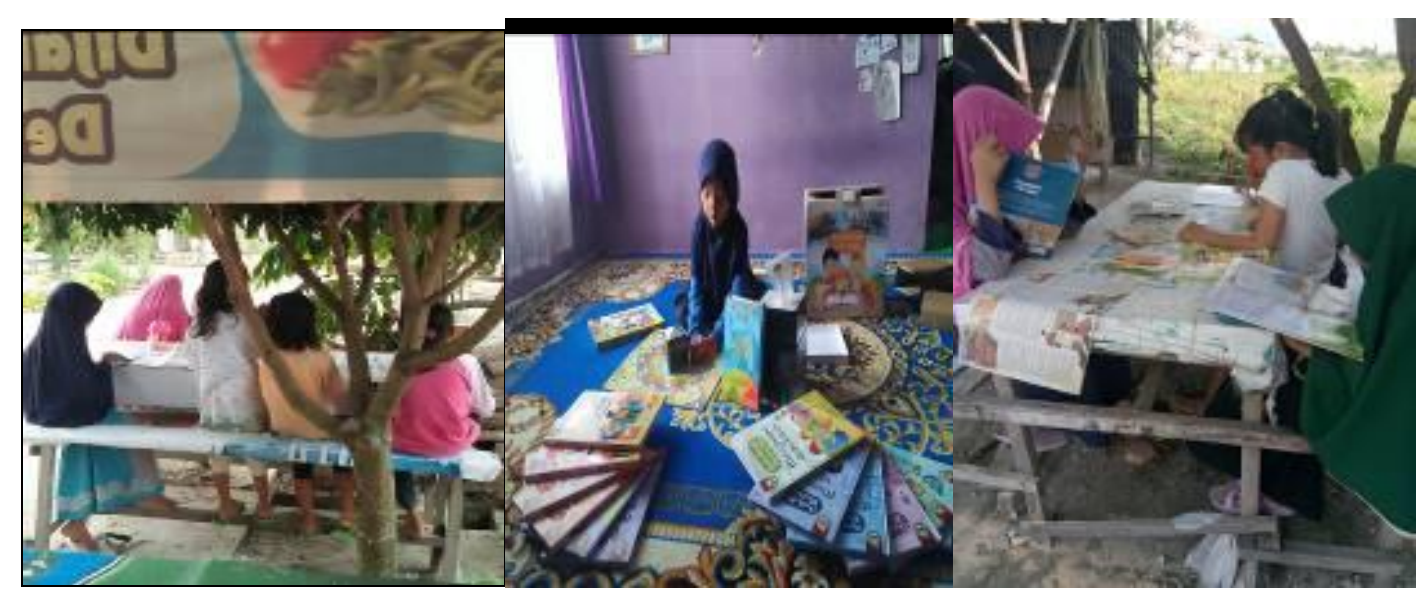

Gambar 2. Kegiatan Membaca dan Bermain Anak Usia Sekolah

Setiap bulan dikumpulkan jumlah anak yang datang ke rumah baca sementara yang dibuat untuk menentukana apakah ada peningkatan minat baca pada anak usia sekolah di Perumahan Bumi Mandala 2 Desa Kualu Kabupaten Kampar. Peningkatan minat baca dan antusias anak untuk membaca di rumah baca sementara dapat telihat dari jumlah kehadiran anak setiap bulannya pada grafik di bawah ini.

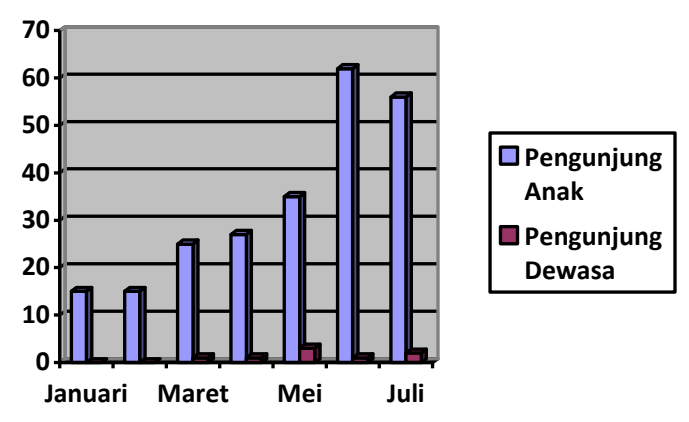

Grafik 1. Jumlah Pengunjung Rumah Baca Sementara 
Selain kegiatan menumbuhkan minat baca pada anak usia sekolah. Kegiatan PkM juga mendonasikan buku bacaan kepada masjid perumahan hasil dari wakaf warga sekitar perumahan dan wakaf dari warga di luar perumahan. Bentuk wakafnya adalah penyerahan buku bacaan tentang Nabi Muhammad SAW kepada pihak pengurus masjid Al-Hidayah Perumahan Bumi Mandala 2 Desa Kualu Kabupaten Kampar.

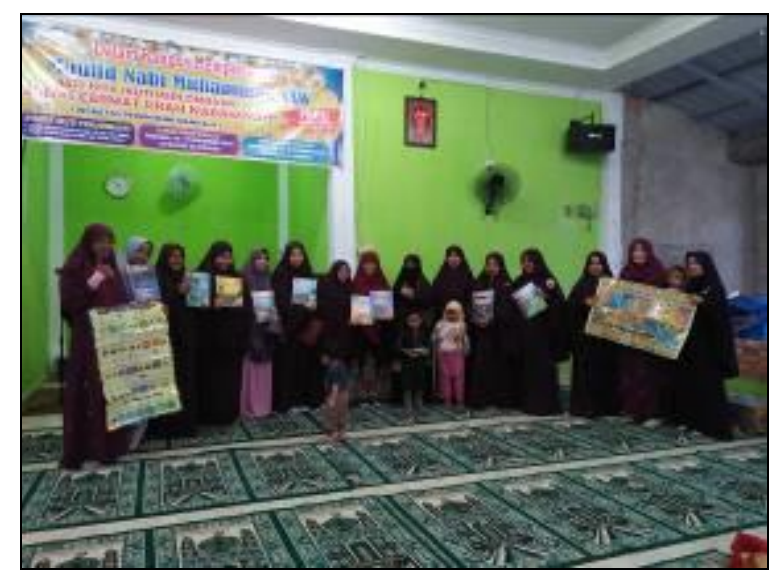

Gambar 3. Penyerahan Buku Wakaf Ke Pengurus Masjid Al-Hidayah Perumahan Bumi Mandala 2

Berdasarkan hasil penelitian tentang Taman Baca Masyarakat yang disampaikan oleh (Suwanto, 2017) menunjukkan bahwa Taman Bacaan Masyarakat dapat digunakan sebagai sarana untuk menumbuhkan minat baca. Keberadaan Taman Baca sangat penting karena sangat dekat dengan masyarakat di akar rumput. Oleh karena itu perlu dikelola dengan baik, sesuai dengan teori-teori pengelolaan perpustakaan yang dapat digunakan sebagai pedoman Taman Baca Masyarakat. Pentingnya pengelolaan lebih lanjut rumah baca sementara ini menjadi Taman Baca Masyarakat merupakan langkah PkM selanjutnya yang akan dilakukan oleh pengabdi.

\section{SIMPULAN}

Kesimpulan dari Pengabdian kepada Masyarakat ini adalah terjadinya peningkatan minat baca anak usia sekolah di Perumahan Bumi Mandala 2 Desa Kualu Kabupaten Kampar. Faktor pendukung tumbuhnya minat baca ini salah satunya adalah adanya himbauan dari pemerintah untuk melaksanakan proses pembelajaran dari rumah. Anak-anak memiliki banyak waktu di rumah dan memerlukan banyak bahan refrensi tambahan untuk tugas yang diberikan oleh guru melalui proses online.

\section{SARAN}

Saran bagi pengabdi berikutnya dapat membuat rumah baca permanen untuk keberlangsungan kegiatan membaca anak ditempat pengabdian berlangsung. Rumah baca tersebut dapat berbentuk Taman Baca Masyarakat.

\section{UCAPAN TERIMA KASIH}

Terimakasih kepada masyarakat Perumahan Bumi Mandala 2 Desa Kualu dan Pengurus RT.09 RW 02 Desa Kualu Kabupaten Kampar atas bantuan terlaksananya kegiatan ini. Terimakasih juga kepada pimpinan LPPM STAI Diniyah Pekanbaru yang memfasilitasi terlaksananya kegiatan ini.

\section{DAFTAR PUSTAKA}

Cordina, L. T. (2020). Ha! Minat Baca Indonesia Terendah Kedua di Dunia, Kok Bisa? Retrieved September 24, 2020, from https://www.genpi.co/berita/33356/ha-minat-baca-indonesiaterendah-kedua-di-dunia-kok-bisa

Forsman, H. (2017). Foster carers' experiences of a paired reading literacy intervention with looked-after children. Child \& Family Social Work, 22(1), 409-418. 
https://doi.org/10.1111/cfs.12258

Kasiyun, S. (2015). UPAYA MENINGKATKAN MINAT BACA SEBAGAI SARANA UNTUK MENCERDASKAN BANGSA. Jurnal Pena Indonesia, $1(1), \quad 79$. https://doi.org/10.26740/jpi.v1n1.p79-95

Khoiruddin, M. A., Taulabi, I., \& Imron, A. (2016). Menumbuhkan Minat Baca Sejak Dini di Taman Baca Masyarakat. Journal An-Nafs: Kajian Penelitian Psikologi, 1(2), 291-319. https://doi.org/10.33367/psi.v1i2.295

Maharani, O. D. (2017). MINAT BACA ANAK-ANAK DI KAMPOENG BACA KABUPATEN JEMBER. Jurnal Review Pendidikan Dasar: Jurnal Kajian Pendidikan Dan Hasil Penelitian, 3(1), 320. https://doi.org/10.26740/jrpd.v3n1.p320-328

Muktiono, J. D. (2003). Aku cinta buku: menumbuhkan minat baca pada anak. Jakarta: PT Elex Media Komputindoo.

Nafisah, A. (2016). ARTI PENTING PERPUSTAKAAN BAGI UPAYA PENINGKATAN MINAT BACA MASYARAKAT. LIBRARIA: Jurnal Perpustakaan, 2(2). https://doi.org/10.21043/LIBRARIA.V2I2.1248

Rahma, \& Maulidia, N. (2015). Strategi Peningkatan Minat Baca Anak (Studi Pada Ruang Baca Anak Perpustakaan Umum Dan Arsip Daerah Kota Malang). Jurnal Administrasi Publik, $3(5)$ 763-769. Retrieved from http://administrasipublik.studentjournal.ub.ac.id/index.php/jap/article/view/862/378

Reason, P., \& Bradbury, H. (2001). Handbook of action research: Participative inquiry and practice. New York: SAGE Publications.

Sumitra, J. I. P. ;, \& Sumini, A. (2019). Peran Guru Dalam Mengembangkan Kemampuan Minat Baca Anak Usia Dini Melalui Metode Read Aloud. Jurnal Ilmiah POTENSIA, 4(2), 115-110. https://doi.org/10.33369/jip.4.2.115-120

Suwanto, S. A. (2017). Pengelolaan TBM Sebagai Sarana Meningkatkan Minat Baca Masyarakat. Anuva, 1(1), 19. https://doi.org/10.14710/anuva.1.1.19-32

Umroh, N. S., Adi, E. P., \& Ulfa, S. (2019). MULTIMEDIA TUTORIAL UNTUK MENUMBUHKAN MINAT BACA ANAK ADHD (ATTENTION DEFICIT HYPERACTIVITY DISORDER). JKTP, 2(1), 45-52. Retrieved from http://journal2.um.ac.id/index.php/jktp/index 